\title{
Roles and strengths of teaching librarians
}

Approved by the ACRL Board of Directors, April 2017

\author{
by the Standards and Proficiencies for Instruction Librarians and Coordinators Revision \\ Task Force
}

\section{Charge and history}

In 2014, the Standards for Proficiencies for Instruction Librarians and Coordinators Revision Task Force was charged "to update and revise the 'Standards for Proficiencies for Instruction Librarians and Coordinators' document in accordance with the recommendations published in the report of the 'Standards for Proficiencies for Instruction Librarians and Coordinator Review Task Force." The Review Task Force recommended that the new document adopt a contextual, holistic approach and wider vision which encompasses the roles and responsibilities of the instruction librarian within the academy, bridge the broader context and potential practical applications, and simplify the document. This new "Roles and Strengths of Teaching Librarians" document represents major change in this revision. Major changes in the revision include language changes such as the shift from "proficiencies" to "roles" and from "instruction librarian" to "teaching librarian," a structural change from a list to a conceptual model, and an altered focus in the document from skills to strengths needed to thrive in each of the roles. This document uses the phrase "teaching librarian," defined as a librarian who teaches in various contexts, and for whom teaching may be all or part of their professional responsibilities. This phrase is used because it is deemed broader and more participatory than "instruction," which is in- dicative of the importance of teaching and the broader educational goals held by librarians.

The following statement from the ACRL Board of Directors addresses the context of the challenges in part for this Task Force as we proceeded to complete our assignment.

At the 2016 ALA Midwinter Meeting in Boston, the ACRL Board of Directors took action to formally adopt the "Framework for Information Literacy for Higher Education." The Board also affirmed its intent to make a decision on the status of the "Information Literacy Competency Standards for Higher Education" at the 2016 ALA Annual Conference, according to the timeline established at the 2015 ALA Midwinter Meeting.

The Board did decide to rescind the "Information Literacy Competence Standards for Higher Education" and their decision was announced at the 2016 ALA national meeting.

The new Framework document remains a framework, not a standard, so that it can move forward as a dynamic, living document with great flexibility and potential.

\section{Approach}

The shift in focus in 2015 from the ACRL "In- 
formation Literacy Competency Standards for Higher Education" to the "Framework for Information Literacy for Higher Education" (Framework) model prompted the task force to closely examine not only the proficiencies themselves but their structure and purpose. In the spirit of the Framework, the Task Force intended to present a more holistic perspective of the range of work done by teaching librarians rather than a list of skills needed to do a specific job. Teaching librarians have increasingly explored innovative and creative roles within their institutions, and the document is intended to reflect the myriad activities, projects, and responsibilities that teaching librarians from a wide variety of institutions may find themselves taking on at different points in their work life and throughout their careers, as well as the characteristics and strengths needed to flourish within these roles. The Task Force also wanted to provide a basic framework from which teaching librarian roles can continually expand within a variety of contexts. In short, this document was designed to act as a bridge between concept and practice.

\section{Context}

The changing higher education environment in which discrete skill sets rapidly evolve, necessitates a broad set of concepts to describe the dynamic roles undertaken by teaching librarians. In keeping with the Framework, which provides "a cluster of interconnected core concepts . . . rather than any prescriptive enumeration of skills," the new "Roles and Strengths" document aims to construct broad and often overlapping categories within which teaching librarians operate, and identifies strengths needed to carry out the daily work within those roles.

The roles of the teaching librarian cannot be fully understood without engagement with the concepts, knowledge practices, and dispositions outlined in the Framework, which sets out "foundational ideas about the information ecosystem" in which librarians work and students learn. The teaching librarian works with students as coach, guide, and mentor as students navigate through this complex information ecosystem at different stages of their personal and cognitive development. Throughout all the roles presented in the new "Roles and Strengths" document, we see potential for improved student learning through application of the rich ideas and context of the Framework.

\section{How the document was created}

The members of the Task Force began by collecting U.S. job postings for academic instruction or information literacy librarians from a six-month period. Postings were analyzed for emerging trends as well as examined quantitatively through word frequency using the Voyant text analysis program. The Task Force also consulted recent literature related to job ads and academic standards, particularly Gold and Grotti's 2013 article, "Do Job Advertisements Reflect ACRL's Standards for Proficiencies for Instruction Librarians and Coordinators?: A Content Analysis." In a summary of their findings, the authors suggested ". . . that professional standards can provide additional guidance regarding specific competencies that go above and beyond the language of job ads." Identified trends from the literature and analysis of job postings included:

- disciplinary and curricular integration knowledge promoting consistency with the larger institution;

\section{Members of the task force}

- Dawn Amsberry, Penn State, member

- Candice Benjes-Small, Radford University, member

- Sara Harrington, Ohio University, cochair

- Sara Miller, Michigan State University, member and IS Executive Committee liaison

- Courtney Mlinar, Austin Community College, member

- Carroll Wetzel Wilkinson, West Virginia University, cochair 
- knowledge about online module creation and appropriate tools;

- a range of teaching skills including a variety of formats and methods;

- knowledge of outcomes, assessment, and scholarly communication;

- collaboration with teaching faculty;

- ability to work with other librarians as teaching and learning trainers in concert with an increasing need for liaison librarians to teach; and

- an understanding of signature disciplinary pedagogies.

Through discussions of these findings, as well as the diverse experiences and institutional contexts among the members of the task force, the seven roles which form the framework of this document were developed: advocate, coordinator, instructional designer, lifelong learner, leader, teacher, and teaching partner. This graphic below illustrates the roles and indicates their interconnected and flexible nature. Librarians would not necessarily have all roles in their work.

\section{Purpose of the roles}

The purpose of the roles is to conceptualize and describe the broad nature and va-

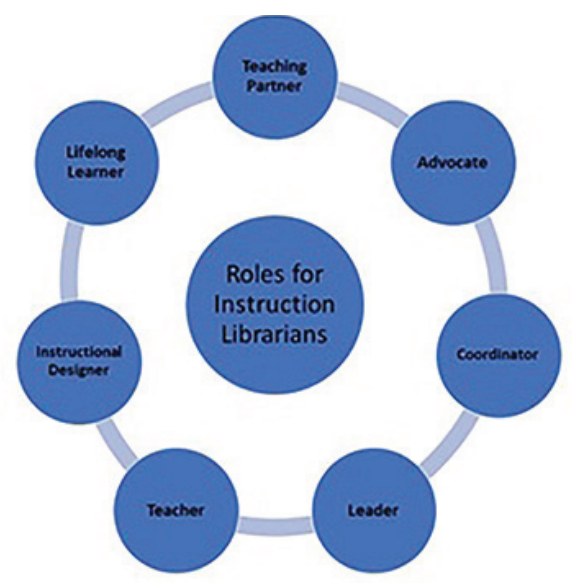

Roles for instruction librarians. broad and encompassing. Just as the Framework is not intended to require librarians to touch upon every frame in every instructional situation, we did not intend that every teaching librarian would or should be working in every role described in the document. We anticipate that many librarians may find themselves identifying more strongly with certain roles over others based upon their positions, institutional contexts, and other factors.

\section{Intended use}

This document is intended to help both clarify roles which may be assumed by a proficient teaching librarian and inspire new roles.

- For hiring institutions, the roles can aid in thinking more specifically about what the riety of the work that

teaching librarians undertake as well as the related characteristics which enable librarians to thrive within those roles. These seven roles, which can and do overlap, are intended to help librarians situate our individual work experiences within the broader work of academic libraries and within academic communities, as well as suggest creative new areas for expansion. The roles also are intended to assist in naming and situating some of the more abstract and unique situations in which librarians find themselves. In this way, the document is purposefully institution envisions for teaching librarians in accordance with their mission, vision, and strategic objectives. While interviewing for new positions, the hiring committee is frequently asked to describe teaching librarian responsibilities. These questions are often answered as "teach information literacy sessions" or "coordinate instruction," but these answers do not define duties as well as roles. These descriptions can be clarified through identifying certain characteristics that are needed to thrive in specific roles.

- For individual librarians, units, or supervisors, the document can help with assisting teaching librarians with goal setting for projects, ideas, or professional development, and articulating how creative or unique work can reflect institutional priorities. The document can help librarians to clarify the major role or roles associated with their specific position in order to lend focus to their work 
and more clearly define their work to others. The roles can also serve as a template for thinking about possibilities for new or unique positions or as a means for re-envisioning and revitalizing educational responsibilities and roles.

- For future librarians, administrators, and instructors in LIS programs, the document provides a nuanced portrait of the range of possibilities and expectations for practicing teaching librarians.

Finally, this document is both based in actual experience and aspirational in nature. It is not intended to be a comprehensive checklist of skills to be attained by every graduating LIS student, or to be fulfilled by a job applicant. It is neither realistic nor intended for any teaching librarian to fully embody all the roles or strengths in their current or desired position. Its intent is to help academic teaching librarians to identify and clarify areas of focus for professional development as well as identify new possibilities for collaboration, expansion, or creative projects.

\section{Roles}

\section{Advocate}

Advocacy by the teaching librarian may involve persuasion, activism, encouragement, and support in many forms. A teaching librarian will need to be able to contextually situate information literacy and communicate its value across a range of audiences in the college/university community. Advocacy is required when working with library leaders and the college or university administration to promote and advance information literacy, student learning, and the information literacy program within the overall library organization.

\section{Strengths:}

- Advocates for professional development opportunities and other forms of career advancement for teaching librarians.

- Communicates the value of information literacy to campus library colleagues.

- Advocates for the library's role in student learning and development across the curriculum.

- Partners with faculty to encourage information literacy within courses and within the curriculum.

- Engages with representatives of campus programs and initiatives to integrate information literacy into co-curricular activities.

- Promotes and advances information literacy to library leaders and campus administrators.

- Advocates for information literacy in relationship to student success in the context of institutional learning goals or learning outcomes.

\section{Coordinator}

A coordinator leads, develops, and maintains a library and/or institution's information literacy program. This role requires highly effective organizational and communication skills in managing multiple simultaneous projects, events, resources, assessment, statistical reporting, and coordinating with administrators as well as academic departments. The coordinator must have diplomatic people skills and confidently navigate the politics of instruction, understanding the climate, culture, and expectations of the stakeholders involved in the institution's information literacy goals.

\section{Strengths:}

- Collaborates effectively and diplomatically, contributing to developing a welcoming culture of inclusive excellence in teaching, learning, and student success.

- Encourages, leads, and empowers other teaching librarians in their professional development and workload management.

- Uses emotional intelligence and political acumen with highly developed, inclusive communication skills to navigate complex and sensitive situations.

- Collaborates in the development of campus-wide information literacy initiatives and goals and facilitates change while generating trust, support, and commitment from administration and faculty partners.

- Creates and cultivates an environment of assessment and value for the information 
literacy program.

- Maintains a consistent and effective information literacy program by leading amidst changes in administration, resources, and funding.

- Assumes responsibility for assessment results, project management, and best practices for instruction programs.

\section{Instructional designer}

The teaching librarian as instructional designer creates educational experiences through designing instructional materials, and developing learning outcomes, assessment tools, and learning objects across diverse learning environments. Learning environments can include face-to-face, hybrid, and online classrooms. The instructional designer makes pedagogical choices appropriate to the educational environment, taking into consideration audience, culture, and accessibility dimensions.

The instructional designer draws upon a solid understanding of learning theory, pedagogical practices such as backward design, outcomes alignment and assessment methodology, as well as technical skill in creating digital instructional materials. Communication and the ability to work collaboratively are also essential to this role. Instructional designers may work closely with both librarians and teaching faculty to design learning experiences that integrate information literacy and enhance instruction.

\section{Strengths:}

- Analyzes the instructional environment, and targets instruction delivery toward appropriate audiences.

- Identifies learning needs of students, and creatively addresses identified needs across multiple contexts drawing on a repertoire of tools, methods, and theories.

- Defines goals and outcomes for learning experiences.

- Creates innovative and appealing lessons with supporting instructional materials aligned with and supporting learning outcomes.

- Assesses the success and impact of learning experiences and makes appropriate adjustments to improve student engagement and learning.

- Stays current with trends and innovations in learning and instructional technologies.

\section{Lifelong learner}

The teaching librarian as lifelong learner is curious, open, and flexible, seeking out new opportunities for continuous learning. Throughout the lifelong learner's professional career, the librarian maintains enthusiasm for teaching through reflective practice and exploration of new approaches to instruction. Lifelong learners are self-motivated in their pursuit of new knowledge, ideas, and experiences.

\section{Strengths:}

- Pursues professional opportunities to improve and refresh teaching skills.

- Maintains currency in both pedagogy and information literacy across disciplines.

- Actively participates in discussions on teaching and learning with colleagues online and in other forums.

- Demonstrates openness to implementing new ideas and new pedagogical practices and to exploring new instructional technologies.

- Participates in local, regional, or national professional associations.

\section{Leader}

The teaching librarian demonstrates leadership both in leading by example and leading across campus contexts. Leading by example includes working to create and maintain a healthy work environment by encouraging new ideas in teaching and learning and by supporting instructional endeavors of librarian colleagues. Librarian leaders model instructional best practices as well as continuous learning and growth, facilitate the sharing of pedagogical ideas and experiences, and support teaching and learning efforts across disciplines and co-curricular areas.

The teaching librarian leads across contexts, including within the library, on campus, in professional contexts, and in the community. Teaching librarians lead alongside teaching faculty and academic staff, working with a diverse range of partners on campus. Librarians 
may co-lead cross-campus collaborations such as curriculum design, learning and technology initiatives, learning outcomes development at course and/or program levels, student success and retention efforts, campus committees, and academic integrity programs. Using a unique, centralized perspective shaped by relationships with students, faculty, and staff, the leader is inclusive and diplomatic. Leading involves effectively navigating campus politics while successfully advancing and managing change. The leader joins other librarians and campus partners in furthering transformative vision and strategic action to advance information literacy as a library and campus-wide priority.

\section{Strengths:}

- Works to model effective change management.

- Builds and models a personal record of excellent instructional practice, including modeling new pedagogies.

- Establishes credibility with other librarians in the workplace.

- Creates an environment of positive learning, trust, and reflection, addressing pedagogical or instruction-related conflicts and encouraging the development of confidence in teaching.

- Advocates for financial and other resources for the instructional program to support human resources and professional development.

- Contributes valuable perspectives as a participant across campus communities.

- Navigates, communicates, and operationalizes information literacy within and among campus entities and structures.

- Builds organizational authority with regard to informational literacy regardless of place within the organizational hierarchy.

\section{Teacher}

This role emphasizes activity in the classroom or other instructional environments where the librarian interacts directly with learners. The teacher employs best practices of teaching and learning for integrating information literacy into higher education. The teacher engages with learners, partners with faculty and administrators, and motivates learning with regard to the importance of information literacy in disciplinary, subject-based, and applied contexts. The teacher employs a learner-centered approach, encouraging learners to be agents in their own learning.

\section{Strengths:}

- Analyzes the needs of each teaching/ learning setting, environment, or group and employs appropriate pedagogical techniques to meet those needs.

- Articulates goals and learning outcomes for information literacy instruction.

- Selects from a repertoire of pedagogies and techniques for diverse learners and learning contexts and experiments with innovative instructional techniques and tools.

- Creates a positive and interactive learning environment that recognizes the importance of context.

- Engages in assessment to ensure that instruction is meeting the defined learning outcomes.

- Demonstrates enthusiasm for teaching and learning and a commitment to professional development, lifelong-learning, and reflective practice.

- Adapts concepts from professional documents and guidelines, such as the "Framework for Information Literacy for Higher Education" in design and content of instructional situations.

\section{Teaching partner}

Teaching librarians have many opportunities to collaborate in different instructional settings with teaching faculty, other librarians, and other campus colleagues. These relationships aim to be partnerships rather than support services. Being a teaching partner requires the teaching librarian to have confidence in the strengths they bring to collaborative relationships with colleagues. This expertise may include broader perspectives about information literacy, formal education in ways that information is organized and classified, expertise in research skills, and knowledge of scholarly communication models and processes. The librarian must also respect the strengths brought 
by the collaborator. In the best teaching partnerships, each person's contributions are valued equally.

The teaching librarian is able to articulate how their contributions are relevant to the instructional context. They may also be involved in designing assignments, assessing students' information literacy skills, or providing feedback on student assignments or projects. Conversations between the librarian and the teaching partner can establish the level of each partner's involvement and explore creative possibilities for further collaboration.

\section{Strengths:}

- Seeks out and engages teaching partners, remaining open to various ways of collaborating.

- Builds mutual respect, trust, and understanding with collaborators.

- Models and encourages effective collaboration with other teaching partners.

- Articulates benefits of collaborating with the teaching librarian.

- With other teaching partners, develops shared vision and goals for the collaboration.

- Negotiates librarian's responsibilities and expectations for the instructional setting with collaborators.

- Brings information literacy perspective and expertise to the partnership.

\section{Bibliography}

ACRL (2012). "Characteristics of Programs of Information Literacy that Illustrate Best Practices: A Guideline." Retrieved from http://www.ala.org/acrl/standards /characteristics.

ACRL Board of Directors. (2016, January 15). Update from the ACRL Board of Directors on the Framework for Information Literacy for Higher Education. Retrieved from http://www.acrl.ala.org/acrlinsider/ archives/11232.

Association of College and Research Libraries. (2016). "Framework for Information Literacy for Higher Education." Retrieved from http://www.ala.org/acrl/sites/ala.org.acrl
/files/content/issues/infolit/Framework_ ILHE.pdf.

Feiman-Nemser, S. (2001). From preparation to practice: Designing a curriculum to strengthen and sustain teaching. Teachers College Record 103(6), 1013-1055. Retrieved from http://www.brandeis.edu/mandel /questcase/Documents/Readings/Feiman _Nemser.pdf.

Fishel, T., Garrison, J., and Herold, P. (2015). "Designing job descriptions for new roles: Integrating scholarly communication and information literacy in liaison job descriptions." Presented at ACRL. Retrieved from http://works.bepress.com/teresa_fishel/28.

Gold, M. L. and Grotti, M. G. (2013). "Do job advertisements reflect ACRL's Standards for Proficiencies for Instruction Librarians and Coordinators? A content analysis." Journal of Academic Librarianship, 39(6), 558-565. doi:10.1016/j.acalib.2013.05.013.

Gold, M. L., and Grotti, M. G. (2014, November 17). "Researcher's Corner: Job Ads and Academic Standards and Proficiencies." Retrieved from https://hiringlibrarians.com /tag/academic-standards/.

Jaguszewski, J., and Williams, K. (2013). "New roles for new times: Transforming liaison roles in research libraries." Washington D.C.: Association of Research Libraries. Retrieved from http://www.arl.org/storage /documents/publications/nrnt-liaison-rolesrevised.pdf.

Mattessich, P. W., Monsey, B. R., \& Amherst H. Wilder Foundation, S. M. (1992). Collaboration: What makes it work: A review of research literature on factors influencing successful collaboration. St. Paul, MI: Amherst H. Wilder Foundation.

Palmer, P. J. (1998). The courage to teach: Exploring the inner landscape of a teacher's life. San Francisco, CA: Jossey-Bass. z 